JCE (Journal of Childhood Education)

Vol. 4 No. 2 Tahun 2020 | Hal. 135 - 151

2620-3278 (E-ISSN), 2598-2184 (P-ISSN)

\title{
IMPLEMENTASI PHYSICAL DISTANCING : PENGELOLAAN PEMBELAJARAN PADA ANAK USIA DINI MELALUI PEMANFAATAN PERANGKAT MEDIA SOCIAL
}

\section{Faizin $^{1}$, Shafiah ${ }^{2}$}

aUniversitas Nurul Jadid, Paiton, Probolinggo, Jawa Timur

${ }^{1}$ faizinsagmpd@gmail.com ${ }^{2}$ sofie.fafi@gmail.com

\author{
Informasiartikel \\ Received : \\ August 13, 2020. \\ Revised : \\ August 26, 2020. \\ Publish : \\ September 09, 2020. \\ Kata kunci: \\ Physical distancing; \\ Pembelajaran, \\ Media sosial
}

\begin{abstract}
ABSTRAK
Penelitian ini bertujuan untuk menganisis tentang pengelolaan physical distancing dalam kegiatan pembelajaran pada anak usia dini di Raudlatul Athfal (RA) Tania, Paiton, Probolinggo, melalui perangkat media sosial. Penelitian ini menggunakan pendekatan kualitatif jenis studi kasus. Hasil penelitian menunjukkan bahwa; Pengelolaan pembelajaran pada anak usia dini melalui pemanfaatan perangkat media social di Raudlatul Athfal (RA) Tania, Paiton, Probolingo, Jawa Timur sebagai berikut; Pembuatan desain perencanaan pembelajaran selama masa pandemic covid-19, mengimplementasikan perencanaan tersebut dalam pembelajaran daring, memonitoring pelaksanaan pembelajaran, pemberian reward and punishment dan melakukan evaluasi secara berkala.
\end{abstract}

Keywords:

Physical distancing;

learning,

social media

\begin{abstract}
This study aims to analyze the management of physical distancing in learning activities in early childhood in Raudlatul Athfal (RA) Tania, Paiton, Probolinggo, through social media tools. This research uses a qualitative approach with case study. The results showed that; Management of learning in early childhood through the use of social media tools in Raudlatul Athfal (RA) Tania, Paiton, Probolingo, East Java as follows; Making learning planning designs during the Covid-19 pandemic, implementing these plans in online learning, monitoring the implementation of learning, giving rewards and punishments and conducting periodic evaluations.
\end{abstract}




\section{PENDAHULUAN}

Pada akhir tahun 2019, Kota Wuhan Provinsi Hubei di China Tengah dikejutkan dengan temuan seorang pasien yang didiagnosis menderita pneumonia yang tidakbiasa. Menurut Beniac et al (2020), penyakit ini menyebar dengan cepat dan diberi nama coronavirus disease 2019 (COVID-19). Susilo et al (2019) menyampaikan bahwa virus ini diduga berasal dari hewan terutama kelelawar, dan vektor lain seperti tikus bambu, unta dan musang (Yuliana, 2020).

Virus ini menyebar cepat, tetapi memiliki tingkat kematian yang lebih rendah. Namun dampak global epidemicnya belum diketahui dengan pasti (Chawla, 2020). Penyebarannya begitu cepat dan bahkan sampai kelintas benua, sehingga akhirnya WHO ( World Health Organization) menetapkan penyebaran virus ini di atas wabah dan endemic, dan sebagian besar negara yang terdaftar di Perserikatan Bangsa Bangsa (PBB) terjangkit virus ini, termasuk juga negara Indonesia (Zaharah, Galia Ildusovna, 2020). Langkah kesiapsiagaan yang dilakukan pemerintahan Indonesia tidak lepas dari prinsip penanggulangan wabah, diantaranya fase pencegahan, fasedeteksi, dan faserespons. Fase pencegahan ini mengacu pada UU Kekarantinaan Kesehatan dan UU Wabah Penyakit Menular sehingga mendukung implementasi tata kelola global penanganan wabah; menyampaikan surat edaran mengenai kesiap siagaan pencegahan Covid-19 kepada Dinas Kesehatan provinsi/kabupaten/kota, Kantor Kesehatan Pelabuhan, dan seluruh rumah sakit; SDM, sarana dan prasarana yang memadai; serta melakukan simulasi penanganan pasien suspect Covid-19 terutama untuk rumah sakit yang ditunjuk sebagai rumah sakit rujukan(Suni, 2020).

Preventif juga dilakukan pada dunia pendidikan dengan kebijakan berupa sekolah-sekolah dan universitas diberhentikan sementara dalam kegiatan tatap mukanya (Wajdi et al., 2020). Begitu pula dengan Lembaga Raudlatul Athfal (RA) 
Tania, yang berada di desa Paiton, Kabupaten Probolinggo, Propensi Jawa Timur. Seluruh siswa tidak diperkenankan untuk melaksanakan kegiatan pembelajaran di sekolah dengan bertatap muka langsung. Siswa dianjurkan untuk tetap di rumah sesuai dengan kebijakan yang telah dikeluarkan oleh pemerintah berupa adanya physical distancing guna memutus rantai persebaran Covid-19 yang mengacu pada surat edaran Mendikbud No. 3 tahun 2020 tentang pencegahan COVID19 pada satuan pendidikan (Wajdi et al., 2020).

Kebijakan Kementrian Agama (KEMENAG) pada surat edaran No 285.1 Tahun 2020, juga menyebutkan tentang upaya pencegahan penyebaran virus Covid19, berupa tetap melakukan proses pembelajaran baik melalui system dalam jaringan (Daring) maupun penugasan berstruktur. Begitu pula dengan kebijakan yayasan dan pimpinan Raudlatul Athfal (RA) Tania Paiton Probolinggo, untuk mencegah persebaran virus covid-19, siswa melakukan kegiatan pembelajaran dari rumah. Berdasarkan kebijakan physical distancing tersebut, yayasan dan kepala memutuskan, bahwa semua siswa Raudlatul Athfal (RA) Tania Paiton Probolinggo harus belajar dari rumah dengan menggunakan online learning.

Pembelajaran secara online merupakan penggunaan teknologi internet dalam penyampaian pembelajaran dalam jangkauan luas yang berlandaskan tiga kriteria yaitu: (1) merupakan jaringan dengan kemampuan untuk menyimpan, mendistribusi dan membagi materi ajar atau informasi, (2) pengiriman sampai ke pengguna terakhir melalui komputer dengan menggunakan teknologi internet yang standar, (3) memfokuskan pada pandangan yang paling luas tentang pembelajaran di balik paradigma pembelajaran tradisional, dengan demikian urgensi teknologi informasi dapat dioptimalkan untuk pendidikan (Irma et al., 2019). 
Lembaga Raudlatul Athfal (RA) Tania, Paiton, Probolinggo telah melaksanakan apa yang menjadi kebijakan pemerintah dengan meliburkan kegiatan belajar mengajar di sekolah dan dialihkan dengan pembelajaran dengan perangkat social media yaitu menggunakan aplikasi Whatsapp (WA).

Menurut Meilinda (2018), berdasarkan hasil penelitiannya didapatkan bahwa media sosial sebagai media yang dapat membantu dalam proses belajar mengajar. Nurhayati ( 2016) juga mengungkapkan bahwa penggunaan media sosial sebagai sebagai media pembelajaran dapat menghilangkan kendala jarak dan waktu.

Lebih lanjut, Irfan et al., (2019) dalam penelitiannya mengungkapkan bahwa penggunaan media sosial secara positif sangat berpengaruh terhadap peningkatan motivasi belajar, sehingga menurut Chalim \& Anwas (2018) peran orang tua adalah mendampingi siswa dalam mengerjakan tugas-tugas dari sekolah penggunaan internet secara bijaksana.

Berangkat dari hal tersebut di atas, dapat dipahami bahwa media social yang digunakan dalam pembelajaran dapat memberikan manfaat yang cukup besar, khususnya dalam kegiatan pembelajaran yang mensyaratkan psychical distancing. Oleh karena itu, peneliti memfokuskan kajiannya pada pengelolaan physical distancing dalam kegiatan pembelajaran pada anak usia dini di Raudlatul Athfal (RA) Tania, Paiton, Probolinggo, melalui perangkat media sosial.

\section{METODE PENELITIAN}

Peneliti menggunakan pendekatan kualitatif jenis studi kasus. Dalam hal ini, peneliti menganalisis dan memahami tentang pengelolaan physical distancing dalam kegiatan pembelajaran pada anak usia dini di Raudlatul Athfal (RA) Tania, Paiton, Probolinggo, melalui perangkat media social, yaitu Whatsapp (WA). Teknik 
pengumpulan datanya dilakukan melalui interview, observasi dan dokumentasi. Adapun teknik analisis datanya dilakukan secara bertahap, yang dimulai dari penyajian data, reduksi data, sampai pada penarikan kesimpulan.

\section{HASIL PENELITIAN}

Hasil penelitian menunjukkan bahwa pengelolaan pembelajaran pada anak usia dini melalui pemanfaatan perangkat media social di Raudlatul Athfal (RA) Tania, Paiton, Probolingo, Jawa Timur sebagai berikut;

\section{Pembuatan Perencanaan}

Berdasarkan kebijakan Kemenag pada surat edaran No 285.1 Tahun 2020 yang menyebutkan tentang upaya pencegahan penyebaran virus Covid-19, berupa tetap melakukan proses pembelajaran baik melalui sitem Dalam Jaringan (Daring) maupun penugasan berstruktur. Menanggapi hal tersebut, maka yayasan bersama Kepala dan komite sekolah mengadakan musyawarah guna merencanakan kelangsungan proses pembelajaran pada anak didik RA Tania selama masa pandemi.

Jamil (2020) menyampaikan bahwa dengan adanya himbauan dari pemerintah terkait wabah saat ini, maka Yayasan, Kepala Sekolah, dewan guru dan komite sekolah, melakukan rapat untuk membahas tentang desain pembelajaran siswa selama berada di rumah, yaitu dengan menggunakan perangkat pembelajaran melalui social media khususnya aplikasi whatsApp.

Dalam kegiatan belajar di rumah guru di Raudlatul Athfal (RA) Tania, Paiton, Probolingo dituntut agar dapat membuat pelajaran semenarik mungkin mengingat siswa belajarnya tidak secara bersama dengan teman-teman yang lain seperti saat 
belajar di sekolah,namun belajarnya didampingi oleh ayah dan bunda di rumah dalam kurun waktu yang tidak sebentar.

Namun demikian,pendidikan embelajaran harus tetap berjalan dengan baik dan lancar, untuk itu pendidik menyiapkan bahan ajar siswa di rumah selama masa pandemi, yang mana bahan ajar ini sesuai dengan Rencana Program Pembelajaran Harian (RPPH) yang telah disusun secara rinci diawal tahun ajaran yang sudah tertuang dalam kurikulum pembelajaran, dengan telah menetapkan tema pembelajaran yang akan diajarkan, hanya saja tempatnya berbeda yaitu proses pembelajaran berada di rumah bukan di sekolah. RPPH yang dibuat tidak harus baku, akan tetapi memuat komponen-komponen yang ditetapkan.

Saleha (2020) juga membenarkan bahwa dengan adanya jadwal guru pendamping membuat tugas lebih terstruktur. Dalam pelaksanaan pengelolaan pembelajaran diperlukan perencanaan yang baik dan matang, pelaksanaan pembelajaran yang sesuai terencana dan pengawasan yang diwujudkan dengan sistem penilaian yang obyektif, jujur, dan menurut standar penilaian yang ditetapkan sebelumnya (Rozalena \& Kristiawan2017).

Namun pembelajaran yang kooperatif juga sangat diperlukan dalam model pembelajaran guna mengoptimalkan hasil belajar siswa.P embelajaran kooperatif itu memiliki beberapa fase, diantaranya;

Fase Pertama, guru menyampaikan tujuan dan memotivasi siswa. Guru menyampaikan semua tujuan pelajaran yang ingin dicapai pada pelajaran tersebut dan memotivasi siswa belajar.

Fase kedua, menyampaikan informasi. Guru menyampaikan informasi kepada siswa dengan jalan mendemonstrasikan atau lewat bahan bacaan. 
Fase ketiga, membimbing proses pembelajaran. Guru membimbing belajar pada saat mereka mengerjakan tugas.

Fase keempat adalah evaluasi. Guru melakukan evaluasi dengan menggunakan strategi evaluasi yang konsisten dengan tujuan pembelajaran.

Fase kelima, memberikan penghargaan. Guru mempersiapkan struktur reward yang akan diberikan kepada siswa. Guru mencari cara untuk menghargai upaya atau hasil belajar siswa.

\section{Implementasi}

Pada masa pandemi Corona Virus Disease 19 ini, banyak hal yang dibatasi, begitu juga dalam dunia pendidikan.S esuai dengan instruksi Presiden dan Kementrian Agama, dimana sekolah diliburkan namun kegiatan pembelajaran tetap berjalan sesuai dengan arahan yang sudah ditetapkan. Alternatif akan media aplikasi WhatsApp (WA) merupakan salah satu media yang saat ini digunakan dalam kegiatan pembelajaran anak selama belajar dari rumah. Hal ini dapat dilakukan mengingat media ini dapat digunakan oleh orang tua anak didik, sehingga dalam kegiatan pembelajaran tetap berjalan dengan lancar dan hasil pembelajaran yang optimal (Jamil, 2020).

Dalam proses pembelajaran di Raudlatul Athfal (RA) Tania Paiton, Probolinggo, pembelajaran pada siswa harus tetap terlaksana meskipun belajar dari rumah masing-masing. Guru sebagai fasilitator yang digantikan oleh orang tua selama belajar di rumah, agar anak tetap mendapatkan materi pembelajaran. Meskipun materi disampaikan melalui media aplikasi WhatsApp (WA), dalam pelaksanaannya peran orang tua sangat dominan menggantikan peran guru, peran itu diantaranya meliputi; orang tua harus menyiapkan perlengkapan siswa untuk belajar, sesuai jadwal yang di berikan sekolah melalui grup whatsApp (WA); orang tua sebagai fasilitator 
menggantikan peran guru, menjelaskan, dan membimbing selama belajar; namun faktor pendidikan dari orang tua yang beragam menjadi alasan akan beragam pula hasil pemahaman yang didapatkan oleh siswa yang akan menentukan keberhasilannya dalam menerima pembelajaran.

Orang tua mengulang apa yang telah dilakukan di sekolah selama belajar di rumah agar siswa tetap mengingat apa yang telah dipelajarinya. Rif'atin (2020) juga menegaskan bahwa; pembiasaan anak selama di sekolah tetap diterapkan selama masa belajar dari rumah, pembiasaan itu berupa perbuatan yang diulang-ulang sehingga menjadi mudah untuk dikerjakan, misalnya pembiasaan anak Raudlatul Athfal (RA) Tania Paiton, Probolinggo dalam mengucapkan salam ketika bertemu dengan guru, pembiasaan sholat berjamaah, membaca doa ketika memulai dan mengakhiri kegiatan, mengaji dengan metode wafa, menghafal surat- surat pendek, menghafal mutiara hadist, menghafal asmaul husna, membaca buku pengenalan alfabet,praktek sholat dhuha dan praktek berwudhu.

Dalam proses belajar ini tentunya tak sedikit hambatan yang ditemui di lapangan. Faktanya adanya orang tua yang masih kurang mengerti tentang penggunaan aplikasi Whatsapp sendiri. Kurang fahamnya orang tua akan tugas yang diberikan oleh guru menyebabkan tidak tersampaikannya materi pembelajaran, yang disebabkan oleh tidak tersedianya paketan data dari orang tua, sehingga ketertinggalan akan informasi terbaru dari whatsApp (WA) grup.

\section{Monitoring}

Dalam pembelajaran pastilah siswa akan menemukan kesulitan yang merupakan hambatan dalam belajar. Salah satunya berupa rendahnya motivasi atau dorongan siswa di Raudlatul Athfal (RA) Tania Paiton, Probolinggo untuk belajar, 
yang menyebabkan menurunnya pencapaian hasil belajar . Disinilah Peran orang tua sangat dibutuhkan.

Namun demikian,dalam pelaksanan pembelajaran yang dilakukan siswa di rumah guru tetap harus melakukan bimbingan walaupun dari jarak jauh. Adanya jadwal guru mempermudah dalam penugasan untuk memonitor proses pembelajaran yang dilakukan siswa di rumah setiap harinya. Di Raudlatul Athfal (RA) Tania Paiton, Probolinggo, guru pendamping berperan aktif untuk mengingatkan siswa terhadap jadwal kegiatan.

Setiap pagi guru menyapa siswa sebelum memberikan tugas, mengingatkan siswa untuk berdoa sebelum dan sesudah melakukan kegiatan tentunya dengan pendampingan oleh orang tua. Guru harus dapat membimbing dan mengarahkan kegiatan belajar siswa sesuai dengan apa yang akan dicapai. Guru harus bisa mengarahkan proses belajar siswa agar mencapai keberhasilan belajar yang optimal. Guru memberikan bantuan kepada siswa agar mereka mampu menyelesaikan tugas yang diberikan, sehingga siswa mampu beradaptasi selama belajar di rumah dalam masa pandemi (Shafiah, 2020).

Siswa tentunya membutuhkan bantuan guru untuk mengatasi kesulitannya yang ditemui selama belajar dari rumah. Oleh karenanya, setiap guru perlu memahami dengan baik teknik dalam membimbing selama belajar dari rumah. Kerjasama dengan orang tua siswa sangat dibutuhkan. Oleh sebab itu, bila ingin pembelajaran tercapai secara maksimal hubungan kerjasama harus terjalin dengan baik. Dengan begitu guru dan orang tua dapat mengetahui perkembangan yang dialami oleh anak.

Melalui kerjasama ini, memudahkan bagi guru dalam memonitor perkembangan anak dalam pembelajaran di rumah. Dengan guru memberikan materi 
pembelajaran dan orang tua memberikan dorongan kepada anaknya guna mendapatkan hasil yang optimal.

Dalam proses pembelajaran di Raudlatul Athfal (RA) Tania Paiton Probolinggo, ada kerjasama yang baik antara guru dan orang tua, sehingga proses pembelajaran yang dilakukan Melalui grup WhatsApp (WA) dapat memberikan pemahaman terhadap peserta didik agar tidak ketinggalan materi pemberlajaran selama masa pandemi Covid-19.

Dengan adanya grup WhatsApp (WA), hubungan antara guru dan orang tua terjalin semakin baik. Peran orang tua juga sangat dibutuhkan, mengingat orang tua adalah pengganti guru selama proses pembelajaran dari rumah. Pengoptimalan hasil belajar siswa dari rumah tergantung pada peranan orang tua. Jadi keberhasilan pembelajaran siswa melalui media social ini tergantung pada aktif dan tidaknya orang tua dalam mendampingi siswa ketika belajar di rumah.

\section{Pemberian Reward and Punishment}

Berlandaskan pada standar tingkat pencapaian perkembangan anak usia dini (STPPA) dalam peraturan menteri pendidikan dan kebudayaan Republik Indonesia nomor 137 tahun 2014 dalam lingkup perkembangan sosial emosional pada perkembangan anak usia 5-6 tahun. Seoarang anak mampu mengetahui akan hak dan kewajibannya. Kemampuan anak ini patut kita hargai dengan memberikan pujian atau sanjungan ataupun berupa hadiah yang kita kenal dengan sebutan reward. Begitupula sebaliknya, pabila seorang anak belum dapat menyelesaikan akan tanggung jawabnya teguran yang akan didapat guna mengoptimalkan potensinya yang kita kenal dengan punisment. 
Reward diberikan kepada siswa yang aktif dan mampu menyelesaikan tugas dengan baik dan benar atas bimbingan guru dan pendampingan orang tua di Raudlatul Athfal (RA) Tania Paiton, Probolinggo. Reward yang diberikan berupa alat untuk pencegahan covid-19 seperti masker dan hand sanitizer. Tak ketinggalan pula, reward juga diberikan untuk orang tua yang aktif mendampingi anak selama masa belajar di rumah. Reward yang diberikan untuk orang tua berupa voucer paketan data. Reward ini diberikan sebagai bentuk apresiasi atas kerjasama yang telah dilakukan oleh orang tua bersama anak selama belajar dari rumah (Shafiah, 2020).

\section{Evaluasi}

Evaluasi merupakan pengukuran dan perbaikan dalam kegiatan yang dilaksanakan. Hal ini merupakan proses pengumpulan, penganalisisan, penafsiran, dan pemberian keputusan tentang data perkembangan dan belajar anak usia dini dalam kegiatan pembelajaran atau program layanan stimulasi yang diselenggarakan di lembaga kelompom anak usia dini. Evaluasi dapat dilakukan dalam berbagai hal. Begitu pula dalam pembelajaran anak usia dini, baik berupa belajar di sekolah maupun daring di rumah.

Pembelajaran daring yang dilakukan di Raudlatul Athfal (RA) Tania Paiton, Probolinggo, dengan melibatkan wali murid tetap melakukan evaluasi akhir semester. Meski dalam tahap pembelajaran daring, namun evaluasi akhir dilakukan agar bisa melihat kemampuan anak didik. Evalusai yang kami lakukan pada masa pandemi covid-19 tetap melibatkan wali murid, namun tetap dengan pantauan guru untuk mendampingi kegiatan yang dilakukan di rumah lewat aplikasi whatshaap (WA).

Rif’atin (2020) menyampaikan evalusi dilakukan selama satu minggu dengan pemberian tugas lewat whatshaap group wali murid, yang nantinya dapat dikerjakan 
di rumah oleh anak didik dengan pendampingan dan pengawasan orang tua. Hasil kegiatan disetor kembali oleh orang tua melewati WA wali murid agar bisa tersampaikan kepada guru.

Dengan melakukan evaluasi daring maka guru bisa mengukur kemampuan siswa lewat hasil kegitan yang dikerjakan di rumah, kemudian di setor melewati aplikasi WhatsApp. Meski hal ini kurang efisien dalam mengukur kemampuan siswa, namun di masa pandemi ini pembelajaran dan evaluasi daring dinilai efektif dalam pemutusan mata rantai penularan covid-19.

\section{PEMBAHASAN}

Salah satu yang dapat dilakukan oleh siswa dari kegiatan di atas selama masa physical distancing adalah memanfaatkan teknologi telepon genggam atau android untuk tetap terhubung dengan guru guna mempermudah dalam proses pembelajaran. Physical distancing pada intinya cukup efektif untuk mencegah penyebaran virus Covid-19. Namun, hal ini tentu perlu disertai dengan upaya pencegahan lainnya, seperti rajin mencuci tangan, membersihkan rumah dengan baik, dan memperkuat daya tahan tubuh dengan mengkonsumsi berbagai vitamin.

Hal lain yang juga dapat kita lakukan adalah menjaga komunikasi dengan orang lain, bisa saling memberi kabar dan semangat, sehingga kita tidak merasa kesepian, sedih, atau terasing. Perasaan-perasaan negatif ini dapat memicu stres dan depresi, serta melemahkan daya tahan tubuh.

Jarak fisik harus tetap dijaga selama masa pandemi penyebaran virus corona, tapi bukan jarak komunikasi di antara guru dan siswa terputus. Keberadaan teknologi seperti internet, dapat dijadikan "media" bagi untuk tetap bertatap muka dan berbicara 
satu sama lainnya, karena kesehatan mental juga tidak kalah penting dari kesehatan fisik.

Sekolah sebagai institusi pencetak generasi yang hidup dimasa mendatang harus mempunyai keperdulian terhadap perkembangan yang terjadi. Jika tidak, maka anak-anak yang kita didik akan tertinggal dengan perkembangan zaman. Karena perkembangan informasi dan komunikasi ini tidak mempunyai toleransi, pilihannya hanya dua, yaitu mampu beradaptasi dan mengadopsi atau tertinggal ke belakang (Nurhayati,2016)

Situs jejaring sosial atau biasa disebut media sosial adalah salah satu media massa berbasis internet yang dapat diakses di mana saja oleh seluruh orang di dunia. Sosial media merupakan platform media yang memfokuskan pada eksistensi pengguna yang memfasilitasi mereka dalam beraktifitas maupun berkolaborasi (Setiadi, 2016).

Perkembangan media sosial membuat kinerja menjadi lebih cepat, tepat, akurat sehingga dapat meningkatkan produktivitas yang dihasilkan. Adapun media sosial yang sering digunakan pada saat ini adalah Facebook, Twitter, Instagram, Path, Tumblr, WhatsApp, dan media sosial yang lainnya. Pemanfaatan media sosial sebagai media belajar mempermudah akses bagi siswa untuk mendapatkan informasi dari guru, begitu pula sebaliknya. Guru lebih mudah memantau siswa tanpa memikirkan jarak dan waktu. Proses pembelajaran di kelas, dan di luar kelas dapat dilakukan dengan media sosial ini,Interaksi sosial, berbagi ide, berbagi pengalaman, dan video dapat dilakukan melalui media sosial (Munsandar, 2018).

Guru sebagai narasumber dan fasilitator dalam menyampaikan materi pelajaran, harus meyakinkan anak bahwa materi pelajaran yang disampaikan memiliki nilai-nilai yang menguntungkan mereka (Hendarwati, 2014). Seorang guru yang 
profesional harus mempunyai kemampuan dalam merencanakan, mengorganisir, menulis, mengevaluasi, mengembangkan hubungan interpersonal, dan mampu membimbing dengan baik selama mengajar dan melatih kemampuan anak (Widayati, 2009). Guru harus dapat menciptakan suasana pembelajaran yang menyenangkan bagi anak untuk meningkatkan motivasi belajarnya apalagi dalam masa pandemi covid-19.

Dalam pembelajaran ini, peran orang tua juga tak kalah penting. Orang tua sebagai pengganti guru haruslah bisa memahami apa yang akan diajarkan kepada anak. Orang tua yang menjadi informan utama berupaya menciptakan lingkungan yang sebaik mungkin untuk anak-anaknya agar tercipta suasana yang menyenangkan (A’yun et al. 2015).

\section{KESIMPULAN}

Di masa pandemi Covid-19, pembelajaran melalui media social khususnya grup Whatsapp (WA) sangat bermanfaat bagi guru dan siswa. Pada masa physical distancing, siswa tetap dapat melaksanakan proses pembelajaran bersama guru walaupun belajarnya dari rumah. Guru dapat mengontrol kegiatan siswa selama belajar di rumah melalui Dalamjaringan (Daring). Guru dapat membimbing siswa selama belajar darirumah melalui media social yang ada.

Raudlatul Athfal (RA) Tania Paiton, Probolinggo, yang ada dibawah naungan Yayasan Nurul Yaqin telah menggunakan metode pembelajaran Dalam jaringan (Daring) dalam penerapan pembelajaran di masa pandemi dengan melibatkan orang tua murid. Keterlibatan orang tua dalam pembelajaran on line sangat penting, bukan hanya anak didik namun orang tua juga dapat belajar menjadi guru pembimbing anak, kepercayaan diri dalam mendidik, serta menstimulus dengan cara alamiah orang tua. 
Di sini dapat kita maknai bahwa keberhasilan belajar siswa dari rumah selain bimbingan dari guru melalui media sosial, peranan orang tua juga sangat menentukan. Kolaborasi tak boleh ditinggalkan antara guru dan orang tua guna mengoptimalkan kemampuan siswa selama belajar dari rumah. Kendala yang diperoleh semasa pembelajaran daring adalah kurangnya sebagian orang tua yang memahami aplikasi khusunya whatshapp (WA) dan sebagian yang tidak mempunyai handphone (HP) android. 


\section{DAFTAR PUSTAKA}

A'yun, Q., Prihartanti, N., \& Chusniatun. (2015). Peran Orangtua dalam Pendidikan Anak Usia Dini (Studi Kasus pada Keluarga Muslim Pelaksana Homeschooling). Jurnal Indigenous, 13(2), 33-40. http://journals.ums.ac.id/index.php/indigenous/article/view/2601

Beniac, D. R., Andonov, A., Grudeski, E., \& Booth, T. F. (2020). Architecture of the SARS coronavirus prefusion spike. Virus Corona (2019-NCoV) Penyebab COVID-19, 3(1), 1-2. https://doi.org/10.1038/nsmb1123

Chalim, S., \& Anwas, E. O. M. (2018). Peran Orangtua dan Guru dalam Membangun Internet sebagai Sumber Pembelajaran. Jurnal Penyuluhan, 14(1), 33-42. https://doi.org/10.25015/penyuluhan.v14i1.19558

Chawla, D. (2020). Change Ideas for First Quality Improvement Project. Indian Journal of Pediatrics, 87(4), 249-250. https://doi.org/10.1007/s12098-02003232-z

Gamar, N. (2019). Implementasi Manajemen Pembiayaan Pendidikan (Study Kasus Mts Darul Khair Masing, Kec. Batui, Kab. Banggai, Sulawesi Tengah). Jurnal Manajemen Pendidikan Islam, 7(1), 11-20.

Hendarwati, E. (2014). PEMANFAATAN MEDIA DALAM PEMBELAJARAN PENGETAHUAN SOSIAL DI TAMAN KANAK-KANAK. Pedagogi, 1(1), $1-30$.

Irfan, M., Nursiah, S., \& Rahayu, A. N. (2019). Pengaruh Penggunaan Media Sosial (Medsos) Secara Positif Terhadap Motivasi Belajar Siswa SD Negeri Perumnas Kecamatan Rappocini Kota Makassar. Publikasi Pendidikan, 9(3), 262-272. https://doi.org/10.26858/publikan.v9i3.10851

Irma, C. N., Nisa, K., \& Sururiyah, S. K. (2019). Keterlibatan Orang Tua dalam Pendidikan Anak Usia Dini di TK Masyithoh 1 Purworejo. Jurnal Obsesi : Jurnal Pendidikan Anak Usia Dini, 3(1), 214-224. https://doi.org/10.31004/obsesi.v3i1.152

Jamil, A. (2020). Interview.

Kemenkes RI. (2020). Pedoman Pencegahan dan Pengendalian Coronavirus Disease (COVID-19). Germas, 0-115.

Lailatul, N., Rohmah, S., \& Wicaksana, A. Y. (2015). Upaya Keluarga untuk Mencegah Penularan salam Perawatan Anggota Keluarga dengan TB Paru. Jurnal Keperawatan, 6(2), 108-116.

MD, W. Z. (2020). The Coronavirus Prevention Handbook 101 Based Tips That Cloud Save Your Life. In Wuhan Center for Disease Control \& Prevention.

Meilinda, N. (2018). Social Media on Campus : The Journal of Society \& Media, 2(1), 53-64.

Munandar, H. wijaya dan A. (2018). Pengembangan Model Pembelajaran Kooperatif Tipe STAD Berbasis Media Sosial. Jurnal Jaffray, Vol. 16(No. 2), 175-196. https://ejournal.bsi.ac.id/ejurnal/index.php/cakrawala/article/download/1283/ 1055

Nurhayati, A. S. (2016). Peran Media Jejaring Sosial Dalam Pembelajaran Abad 21. Prosiding Temu Ilmiah Nasional Guru, 1-9(November), 621-631.

Rif'atin. (2020). Interview.

Risnawaty, G. (2016). Faktor Determinan Perilaku Cuci Tangan Pakai Sabun (Ctps) 
Pada Masyarakat Di Tanah Kalikedinding. Jurnal PROMKES, 4(1), 70-81. https://doi.org/10.20473/jpk.v4.i1.2016.70-81

Rozalena, \& Kristiawan, M. (2017). Pengelolaan Pembelajaran Paud Dalam Mengembangkan Potensi Anak Usia Dini. JMKSP (Jurnal Manajemen, Kepemimpinan, Dan Supervisi Pendidikan), 2(1), 76-86. https://doi.org/10.31851/jmksp.v2i1.1155

Saleha, L. (2020). Interview.

Setiadi, A. (2016). Pemanfaatan media sosial untuk efektifitas komunikasi. Jurnal Humaniora, 16(2), 1-7. https://ejournal.bsi.ac.id/ejurnal/index.php/cakrawala/article/download/1283/ 1055

Shafiah. (2020). Interview.

Sufiati, V., \& Afifah, S. N. (2019). Peran perencanaan pembelajaran untuk performance mengajar guru pendidikan anak usia dini. Jurnal Pendidikan Anak, 8(1), 48-53. https://doi.org/10.21831/jpa.v8i1.26609

Suni, N. S. P. (2020). Kesiapsiagaan Indonesia Menghadapi Potensi Penyebaran Corona Virus Disease. Bidang Kesejahteraan Sosial Info Singkat, 12(3), 1418.

Susilo, A., Rumende, C. M., Pitoyo, C. W., Santoso, W. D., Yulianti, M., Herikurniawan, H., Sinto, R., Singh, G., Nainggolan, L., Nelwan, E. J., Chen, L. K., Widhani, A., Wijaya, E., Wicaksana, B., Maksum, M., Annisa, F., Jasirwan, C. O. M., \& Yunihastuti, E. (2019). Coronavirus Disease 2019: Tinjauan Literatur Terkini. Jurnal Penyakit Dalam Indonesia, 7(1), 45-67. https://doi.org/10.7454/jpdi.v7i1.415

Tim Kerja Kementerian Dalam Negeri. (2013). Pedoman Umum Menghadapi Pandemi Covid-19 Bagi Pemerintah Daerah: Pencegahan, Pengendalian, Diagnosis dan Manajemen. Journal of Chemical Information and Modeling, 53(9), 1689-1699. https://doi.org/10.1017/CBO9781107415324.004

Wajdi, M. B. N., Iwan Kuswandi, Umar Al Faruq, Zulhijra, Z., Khairudin, K., \& Khoiriyah, K. (2020). Education Policy Overcome Coronavirus, A Study of Indonesians. EDUTEC : Journal of Education And Technology, 3(2), 96-106. https://doi.org/10.29062/edu.v3i2.42

Widayati, T. (2009). Pengembangan Media Pembelajaran Tutor Paud Dalam Menggali Perilaku Kerjasama Anak Usia Dini Melalui Gerak Dan Lagu. Jiv, 4(2), 113124. https://doi.org/10.21009/jiv.0402.1

Wowsome, T. (n.d.). COVID-19 Persiapkan dengan Hati-.

Yuliana. (2020). Corona virus diseases (Covid -19); Sebuah tinjauan literatur. Wellness and Healthy Magazine, 2(1), 187-192. https://wellness.journalpress.id/wellness/article/view/v1i218wh

Zaharah, Galia Ildusovna, A. W. (2020). Impact of Corona Virus Outbreak Towards Teaching and Learning Activities in Indonesia? Journal of Chemical Information and Modeling, 7(3), 1456-2356. https://doi.org/10.1017/CBO9781107415324.004 